\title{
A Study on Improving the Application of Green ICT Convergence Technology for a Smart City
}

\author{
Minwoo Jang ${ }^{1}$, Ri Ryu ${ }^{2}$ and Yongseong $\mathrm{Kim}^{3 *}$ \\ ${ }^{1,2,3}$ The Graduate School of Techno Design, Kookmin University, Jeongneung- \\ dong, Seongbuk-gu, Seoul, 136-702, Korea

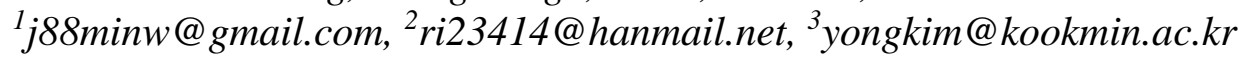

\begin{abstract}
A smart city is a city in which urban functions are networked using Information \& Communications technology. Various studies on this new type of city are being carried out worldwide with the aim of solving the urban problems and environmental problems that are occurring due to the acceleration of urbanization. As a result, the establishment of the smart city, a new type of city, through the use of ICT convergence technologies has emerged as a new interest. The smart city can be considered as a future city type that addresses urban problems and environmental problems and responds to industrial and economic developments by applying 4th industrial revolution convergence technologies such as robotics, artificial intelligence, Internet of Things, automated guided vehicles, $3 D$ printing and nanotechnology to a city. Therefore, the definition of smart city and ICT convergence technologies developed with the 4th industrial revolution were considered, and cases in which green ICT was applied were analyzed in this study. The purpose of this study is to establish preliminary data for the development of an advanced smart city in the future, by proposing improvement points for green ICT based on the case analysis.
\end{abstract}

Keywords: Smart city, Information \& Communications Technology, Green ICT, Energy Saving, Sustainable City

\section{Introduction}

\subsection{Background and Purpose of Study}

The trend of urbanization is expected to be accelerated due to the increase in the urban population that accompanies the growth of emerging economies and the rapid industrial development that is taking place throughout the world. Currently, 50\% of the world population has moved to or live in a city due to the acceleration of urbanization, and $80 \%$ of all resources are now being consumed in cities. The global trend of urbanization can be interpreted as reflecting economic development both directly and indirectly, presenting the possibility that a new type of city will emerge [1]. However, this trend also has negative factors for quality of life such as an increase in the population density, traffic, environmental pollution, crime rate and urban crowding in the city. In this sense, unrestrained urban development does not have only positive effects. To address these negative factors, various studies have been ongoing on the establishment of a new type of city that incorporates the technologies of the 4th industrial revolution. The six fields of artificial intelligence, robotics, Internet of Things (IoT), automated guided vehicles, 3D printing and nanotechnology are becoming the core of the 4th industrial revolution through convergence with Information \& Communications technology [2]. Also, the World Economic Forum expects that industries such as medical services, city infrastructure, production, healthcare, agriculture, energy and transportation, which

Received (November 8, 2017), Review Result (January 25, 2018), Accepted (February 2, 2018) 
together account for more than $2 / 3$ of the global economy, will be changed dramatically over the next 10 years by IT [3]. In this context, the smart city is being recognized as a new type of city, in which ICT convergence technologies developed based on the 4th industrial revolution are applied.

In particular, green ICT is the ICT convergence technology that can address the sustainability and eco-friendly elements of the smart city. While the smart city is being developed under this concept, various studies are also being carried out on the application of ICT convergence technologies to eco-friendly environments in buildings. Also, it is expected that green ICT will solve various environmental issues faced in cities related to water quality, atmospheric pollution and waste, further improving quality of life. Therefore, the purpose of this study is to analyze various ICT convergence technologies based on the green ICT applied to the previously established smart cities, and to propose improvement measures and the possibility of applying green ICT convergence technologies in order to implement an advanced smart city in the future.

\subsection{Method and Range of Study}

In this study, the question of smart cities, which have become an issue for futureoriented urban development, and measures to establish them were analyzed as a plan to solve the urban problems and environmental problems occurring due to rapid urbanization. ICT convergence technologies were analyzed based on the smart cities in England, Holland, China and Japan that are both pioneers in the smart city area and role models for the establishment of future smart cities. Based on these findings, the goal is to propose a feasible way of implementing an automatic eco-friendly system of future smart cities by applying advanced green ICT based on the green ICT currently applied to smart cities in each country. 1.2 Method and Range of Study.

In this study, the question of smart cities, which have become an issue for futureoriented urban development, and measures to establish them were analyzed as a plan to solve the urban problems and environmental problems occurring due to rapid urbanization. ICT convergence technologies were analyzed based on the smart cities in England, Holland, China and Japan that are both pioneers in the smart city area and role models for the establishment of future smart cities. Based on these findings, the goal is to propose a feasible way of implementing an automatic eco-friendly system of future smart cities by applying advanced green ICT based on the green ICT currently applied to smart cities in each country.

Table 1. Research Range and Methods

\begin{tabular}{c|l|l}
\hline \multicolumn{2}{c|}{ Classification } & \multicolumn{1}{c}{ Contents of material } \\
\hline \multirow{2}{*}{ Range of study } & \multicolumn{1}{c|}{ Target country } & England, Holland, China, Japan \\
\cline { 2 - 3 } Method of study & $\begin{array}{l}\text { Green ICT among Information \& Communications } \\
\text { technologies (ICT) applied to each city }\end{array}$ \\
\hline \multirow{2}{*}{$\begin{array}{l}\text { - Definition of smart city and concept of } \\
\text { Information \& Communications technologies (ICT) } \\
\text { - Analysis of green ICT cases applied to the smart } \\
\text { city } \\
\text { - Proposal of supplementation points for green ICT } \\
\text { through the analysis of cases }\end{array}$} \\
\hline
\end{tabular}




\section{Smart City and Information \& Communications Convergence Technologies (ICT)}

\subsection{Definition of Smart City}

The smart city is a new urban planning trend that has been recognized throughout the world since the dawn of the 4th industrial revolution. Approximately 150 large smart city projects are being carried out throughout the world, and it is expected that approximately $\$ 1.24$ trillion will be invested worldwide in establishing smart cities by 2019 , with investments seeing an $18 \%$ annual growth rate [4]. This trend is being expanded from advanced countries such as the US and European countries to emerging economies such as China and India, as well as developing countries.

The smart city is a new city trend that has been defined in various ways. Currently, the smart city is defined as an intelligent city in which various public functions, ranging from the transportation system to the power grid including administration, welfare, education, economy and industry, are facilitated through ICT infrastructures [5]. This definition addresses the question from a technical perspective, and the ICT application is most important aspect in the technical definition of a smart city.

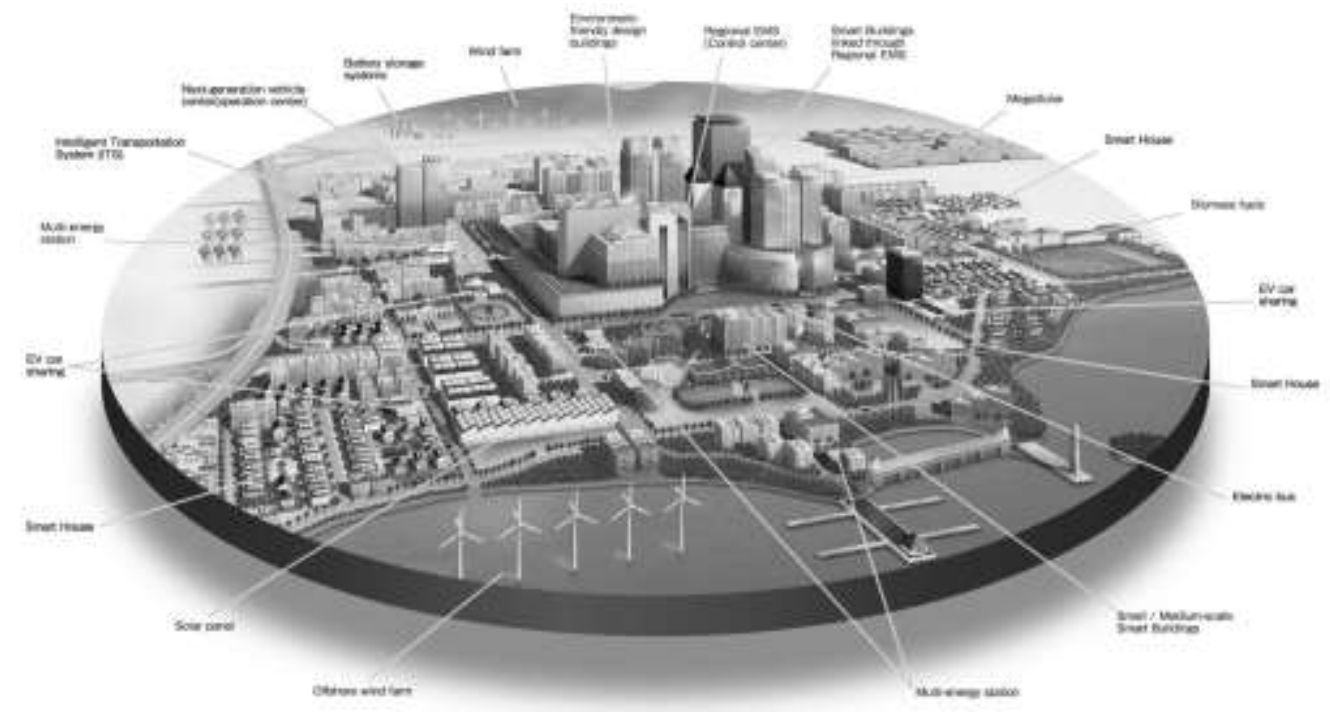

Figure 1. Smart City Concept Map [6]

\subsection{Information \& Communications Convergence Technologies (ICT)}

\subsubsection{Concept of Information \& Communications Convergence Technologies (ICT)}

ICT is an acronym for Information \& Communications Technologies, and encompasses the concept of both "Information Technology" and "Communications Technology." Communication is added to IT in order to place a greater emphasis on the information sharing and communication process. Therefore, it can be considered that Information \& Communications technologies encompass all methods of searching, collecting and delivering information using hardware and software. 


\subsubsection{Elements of Information \& Communications Convergence Technologies (ICT)}

Table 2. List of ICT Convergence Technologies

\begin{tabular}{|c|c|c|}
\hline Category & Types & Contents \\
\hline $\begin{array}{l}\text { Smart Home } \\
\text { System }\end{array}$ & $\begin{array}{l}\text { - Smart Home Platform } \\
\text { - Smart Home Network } \\
\text { - Green Home } \\
\text { - Smart Home Management } \\
\text { - Home Energy Management System } \\
\text { - Fuel Cell }\end{array}$ & $\begin{array}{l}\text { - Networking of information and living } \\
\text { appliances through SHN } \\
\text { - Consideration of human-centered } \\
\text { service environments } \\
\text { - Automatic control system }\end{array}$ \\
\hline $\begin{array}{l}\text { Smart } \\
\text { Building } \\
\text { System }\end{array}$ & $\begin{array}{l}\text { - Building Energy Management } \\
\text { System } \\
\text { - Smart Building Platform } \\
\text { - Smart Building Energy Network } \\
\text { - Smart Building Network } \\
\text { - Energy Management } \\
\text { - Smart Building Management }\end{array}$ & $\begin{array}{l}\text { - Networking of the whole building } \\
\text { through SBN } \\
\text { - Controlling the whole building through } \\
\text { SBM } \\
\text { - Monitoring the energy consumption of a } \\
\text { building through BEMS }\end{array}$ \\
\hline $\begin{array}{l}\text { Smart } \\
\text { Transportation } \\
\text { System }\end{array}$ & $\begin{array}{l}\text { - Intelligent Traffic Management } \\
\text { - Smart Parking System } \\
\text { - Smart Navigation System } \\
\text { - Parking \& Stopping payment system }\end{array}$ & $\begin{array}{l}\text { Intelligent and network technology of } \\
\text { vehicle domains using ITM } \\
\text { Establishment of automated } \\
\text { transportation system, using automatic } \\
\text { parking and automatic driving system }\end{array}$ \\
\hline $\begin{array}{c}\text { Smart } \\
\text { Government }\end{array}$ & $\begin{array}{l}\text { - Real-time Population Information } \\
\text { System } \\
\text { - Urban Security Monitoring System }\end{array}$ & $\begin{array}{l}\text { - Facilitating communication between the } \\
\text { government and people through a } \\
\text { combined wired-wireless infrastructure } \\
\text { - Automatic monitoring system for } \\
\text { security and crime prevention in a city }\end{array}$ \\
\hline Green ICT & $\begin{array}{l}\text { - Management } \\
\text { - Measure } \\
\text {-Evaluation }\end{array}$ & $\begin{array}{l}\text { - Aims at reducing energy consumption } \\
\text { and improving efficiency } \\
\text { - Responds to environmental pollution } \\
\text { related to industrial development } \\
\text { - Responds to national climate change } \\
\text { - Technology for a sustainable city }\end{array}$ \\
\hline
\end{tabular}

The smart home system is the technology that connects and automatically controls intelligent information and living appliances through the network or assures their required environments according to user needs in order to prepare a human-centered service environment [7]. The smart building system is the system that connects and controls systems in the building through the network using IT solutions and automatic control systems. The smart transportation system is an intelligent automatic transportation control system that solves transportation problems that occur in the city, such as traffic congestion and parking problems. This new ICT convergence technology is equipped with a vehicle domain network and intelligent electronic control unit (ECU), and responds according to road conditions and the transportation system.

Green ICT is the technology that aims to ensure the sustainability of the smart city by reducing energy consumption and toxic emissions, revitalizing recycling and improving energy efficiency based on ICT convergence technologies. Also, this technology promotes the transition to a low-carbon society and responds to national climate change by integrating green ICT with various industrial technology fields in the city, and maximizing the efficient use of energy and resources [8]. 


\subsubsection{ICT Application Cases}

Table 3. List of ICT Types Applied to a Smart City

\begin{tabular}{|c|c|c|c|c|c|}
\hline \multirow{2}{*}{\multicolumn{2}{|c|}{$\begin{array}{l}\text { Information \& } \\
\text { Communications } \\
\text { Technologies }\end{array}$}} & \multicolumn{4}{|c|}{ Smart City } \\
\hline & & Glasgow (UK) & $\begin{array}{l}\text { Amsterdam } \\
\text { (Netherlands) }\end{array}$ & $\begin{array}{l}\text { Shanghai } \\
\text { (China) }\end{array}$ & $\begin{array}{c}\text { Yokohama } \\
\text { (Japan) }\end{array}$ \\
\hline \multirow{6}{*}{$\begin{array}{l}\text { Smart Home } \\
\text { System }\end{array}$} & $\begin{array}{l}\text { Smart Home } \\
\text { Platform }\end{array}$ & $\bullet$ & & $\bullet$ & \\
\hline & $\begin{array}{l}\text { Smart Home } \\
\text { Network }\end{array}$ & $\bullet$ & $\bullet$ & $\bullet$ & $\bullet$ \\
\hline & Green Home & $\bullet$ & $\bullet$ & & \\
\hline & $\begin{array}{l}\text { Smart Home } \\
\text { Management }\end{array}$ & & & $\bullet$ & \\
\hline & $\begin{array}{l}\text { Home Energy } \\
\text { Management }\end{array}$ & & & & $\bullet$ \\
\hline & Fuel Cell & & $\bullet$ & & \\
\hline \multirow{3}{*}{$\begin{array}{l}\text { Smart } \\
\text { Building } \\
\text { System }\end{array}$} & $\begin{array}{l}\text { Building } \\
\text { Energy } \\
\text { Management } \\
\end{array}$ & $\bullet$ & $\bullet$ & $\bullet$ & $\bullet$ \\
\hline & $\begin{array}{l}\text { Smart Building } \\
\text { Platform }\end{array}$ & • & & & \\
\hline & $\begin{array}{l}\text { Smart Building } \\
\text { Network }\end{array}$ & $\bullet$ & $\bullet$ & $\bullet$ & $\bullet$ \\
\hline \multicolumn{2}{|c|}{$\begin{array}{ll} & \text { Intelligent } \\
\text { Smart } & \text { Traffic } \\
\text { TransportationManagement }\end{array}$} & & $\bullet$ & & $\bullet$ \\
\hline System & $\begin{array}{l}\text { Smart Parking } \\
\text { System }\end{array}$ & & $\bullet$ & & \\
\hline \multirow{2}{*}{$\begin{array}{l}\text { Smart } \\
\text { Government } \\
\text { System }\end{array}$} & $\begin{array}{l}\text { Real-time } \\
\text { Population } \\
\text { Information }\end{array}$ & & & $\bullet$ & \\
\hline & $\begin{array}{l}\text { Urban Security } \\
\text { Monitoring } \\
\text { System }\end{array}$ & & & $\bullet$ & \\
\hline \multirow{3}{*}{ Green ICT } & Management & $\bullet$ & $\bullet$ & $\bullet$ & $\bullet$ \\
\hline & Measure & $\bullet$ & $\bullet$ & $\bullet$ & $\bullet$ \\
\hline & Evaluation & $\bullet$ & $\bullet$ & $\bullet$ & $\bullet$ \\
\hline
\end{tabular}

In 2007, the British government established a special committee called Technology Strategy Board (TSB) for future construction and technology-centered innovation in England, and selected Glasgow as a pilot smart city. The British government planned the Glasgow smart city, which accomplishes low carbon energy technology, energy-saving residential area and heating energy saving by applying green ICT in order to establish a sustainable community. Also, a website was developed for the collection and management of information on factors such as safety, transportation, health, energy, environment, GDP and city population for analysis in order to achieve the development of Glasgow smart city [9].

The Dutch government intended to establish an intelligent smart city in Amsterdam, but with the recent emergence of environmental problems, it set the main goal as reducing carbon dioxide emissions based on green ICT, according to the eco-friendly convention with the EU. This had the effects of reducing traffic congestion by controlling the movement of vehicles through the smart transportation system's intelligent traffic management, while also reducing the consumption of resources and energy by encouraging the use of bicycles or public transportation. Efforts are also being made to minimize the consumption of resources by using electricity as fuel for industrial transport vehicles and public transportation vehicles. 
The Chinese government is currently promoting and carrying out careful urbanization policies in order to minimize the adverse effects of rapid economic development, such as increased energy consumption and environmental pollution, while maintaining growth. The urbanization project that is currently being carried out in China aims at significantly changing the quality of the city using Information \& Communications technologies through the construction and management of security systems, infrastructures and smart city technologies [10].

As there was a growing interest in new \& renewable energy and a sudden rise in demand for such energy after the Fukushima accident in 2011, the smart grid project based on green ICT was actively promoted in Japan, becoming the key project in the area of urban planning. As a result, various projects including 'Establishing an energy management system,' 'Promoting the use of a home battery,' 'Integrated control of power and heat' and 'Electrical power supply to batteries of electric vehicles and homes (V2G)' are being carried out as pilot smart city projects in Japan [11].

\section{Trend and Problem Factors of Green ICT}

\subsection{Trend of Green ICT}

\subsubsection{Trend of International Green ICT}

In the US, the Environmental Protection Agency (EPA) and the Department of Energy (DOE) carry out the green ICT policies under the leadership of the federal government. In recent years, each state government has been promoting the development of policies while the federal government plays the role of supporting and coordinating such policies. The federal government began to apply the "Energy Star" energy efficiency program that was initiated by the EPA to computers for the first time in 1992[12], and its application range has gradually been expanded to become an international standard. The EPA announced that thanks to these policies, greenhouse gas emissions were reduced by an average of 30 million tons per year and the cost of electricity production was reduced by 16 billion USD [13].

Green ICT in England has been developed through policies related to the establishment of green infrastructure in the public sector according to priority. The performance of policies is analyzed through the green ICT Scoreboard, with the aim being a reduction in carbon dioxide emissions [14]. The British government presented 18 methods for using ICT in public buildings, with the goal being carbon neutrality, and announced their plan to apply such methods to the waste field. The British government discloses behavioral change, methods and guidance for the promotion of a green city to the general public, developing participatory green ICT led jointly by local governments, each government department and the public.

Green ICT in Japan is promoted under the leadership of the central government, and is actively applied to economic and industrial development using ICT convergence technologies. Greater economic efficiencies are being achieved using green ICT, and the development of green ICT is carried out through active linkages with international organizations in order to achieve early global competitiveness in this area.

The OECD approaches ICT and environmental problems with the aim of identifying an opportunity to make the best use of ICT, through excellent cases and ground-based policies. The ITU, which is UN-affiliated organization, handles the standardization business, using ICT to evaluate the reduction of carbon dioxide emissions.

The EU has designated smart grid, building, lighting and photonics, transportation and logistics, and production as five fields where industrial energy can be saved using ICT [15]. Accordingly, the EU evaluates the exemplary cases and energy efficiency rating 
based on the smart city project in each country, reflecting and leading the eco-friendly policies of each government.

\subsubsection{Trend of Green ICT in Korea}

Korean government decided to pursue a 'Low-carbon green growth' paradigm through the development of green ICT based on sustainable economic growth in response to global climate change [16]. The green growth plan was established for each government department, active discussions were held, and green ICT-related plans were promoted based on the characteristics of each government department.

The Ministry of Knowledge Economy presented 'Strategies of IT industry for green growth' in order to lead low-carbon green growth [17]. The Ministry of Knowledge Economy observes the role of ICT in the industry and energy and promotes 'green' policies that can be achieved through ICT. Therefore, it is expected that green ICT will play a key role in reducing energy consumption in industrial fields and society, such as transportation and buildings using ICT [18].

The Ministry of Public Administration and Security has announced its 'green information promotion plan for low-carbon green growth' [19], promoting policies to improve efficiency in natural resources and energy use through the efficient management of information resources and active utilization of IT. These plans are being carried out with the goal of reducing carbon dioxide emissions by over $10 \%$ a year.

\subsection{Obstacles to the Development and Distribution of Green ICT}

ICT has been harnessed around the world in efforts to reduce energy consumption in industry and society, but there is a lack of an inventory of greenhouse gas emissions in the ICT field. The status data of greenhouse gas emissions is analyzed separately using ICT as an energy saving field, but it is judged that it is necessary to separate the ICT application for reducing greenhouse gas emissions and establish an inventory for green ICT. Furthermore, there is lack of information regarding carbon and energy consumption of ICT using LCA. Currently, the life-cycle energy assessment of ICT products is not included in the industrial energy assessment field. This means that we lack an objective assessment of energy use including greenhouse gas and energy consumption from the use of ICT products using LCA; for this reason, it is judged that there is a high likelihood that our energy consumption data for the public and private sector is skewed.

High utilization and proficiency of ICT are essential for revitalizing green ICT. However, there is a lack of an established IT infrastructure and expert ICT technologies in this area. For this reason, it is considered that it would be difficult to revitalize the application of green ICT, given that the social requirements have not yet been met. Currently, ICT developments and related policies that could strengthen the industry and economic society are being promoted in each field in the international community, but the prevailing opinion is that relevant technical developments and policies in the service field are inadequate. It is judged that the growth of green ICT can be realized only when the perception that the application of ICT only promotes industrial and economic development changes to a belief that it can be used to build sustainable cities and ecofriendly communities.

\subsection{Direction of Improvement for the Development and Distribution of Green ICT}

It is necessary to prepare and reinforce the leadership role of the public in saving energy in industries and society based on the development of ICT throughout the world. To revitalize green ICT, the development of green ICT in each country based on relevant guidelines and institutional support is deemed important considering that the UN or Greenpeace first applied green ICT. It is expected that through this process, each 
government will revitalize green ICT based on policy, preparing the foundation to distribute green ICT in the private sector.

Therefore, it is necessary to improve the global recognition and utilization of green ICT. The revitalization of green ICT in the private service field as well as the public sector should be supported by the capacity of individuals to utilize ICT. Since the capacity of individuals to utilize ICT plays a key role, it is judged that systematic education and active promotion are necessary. Based on this premise, the revitalization and distribution of green ICT between the government and corporations also should be reinforced. If energy savings can be achieved through the government's green ICT projects, and the policy orientation is aimed at promoting energy efficiency in the leading corporations, it is judged that the establishment and utilization of the ICT infrastructure will be further promoted. If the barrier between the government and corporations in the area of ICT investment and development is removed, it is expected that the utilization of green ICT as well as other ICT will be improved. Also, it is judged that it will be possible to establish a highly advanced smart city compared to the existing smart cities through the development of various ICT.

\section{Conclusion}

Various studies including studies on eco-friendly sustainable cities and energy saving are being carried out in the international community to address the needs created by climate change and increased energy consumption. At the same time, the ICT developed due to the 4th industrial revolution are becoming the key technologies to lead the future. The combination of these factors has led to the establishment of the "smart city" concept, with pilot smart cities in England, Holland, China and Japan being developed. Currently, the smart city is defined as an intelligent city in which various public functions, ranging from the transportation system to the power grid including administration, welfare, education, economy and industry, are facilitated through an advanced ICT infrastructure, and it is established based on technologies for searching, collecting and delivering information using hardware and software called ICT. ICT is being developed in various fields including architecture, the economy, industry and energy, and in particular, the development of green ICT should be achieved as a priority for sustainable cities and communities.

Green ICT is ICT for controlling the sustainability and eco-friendly elements of a city. These technologies become the basis for future industries and promote the sustainability of smart cities by reducing energy consumption, reducing the emission of toxic chemicals, revitalizing recycling and improving energy efficiency based on ICT convergence technologies. Also, this technology promotes the transition into a low-carbon society and responds to national climate change by integrating green ICT with various fields of industrial technology in the city and maximizing the efficient use of energy and resources. In the international community, green ICT is being applied to various fields including greenhouse gas / carbon dioxide reduction, energy efficiency, improving the traffic system, smart homes, smart buildings and smart government. In Korea, the application of such technologies is being carried out with the goal of reducing carbon dioxide emissions based on 'Green growth.' However, no inventory for green ICT has been established, and there is a lack of data regarding the energy consumption and carbon emissions of ICT products, as well as a lack of ICT utilization and proficiency. Therefore, this hampers the utilization of green ICT, and for this reason it is judged that it is difficult to apply green ICT for establishing a smart city.

Therefore, the definitions of smart city and ICT convergence technologies were considered in this study, in order to identify specific problems with current green ICT through an analysis of Information \& Communications technologies based on smart cities 
overseas. Measures to improve green ICT were derived by considering the future trend, sustainable city and eco-friendly industry and society based on the identified problems.

First, it is necessary to prepare and reinforce the leadership role of the public in saving energy in the industries and society based on the development of ICT. It is necessary to secure institutional support and guidelines based on international organizations, and promote the technical developments in each country. Second, it is necessary to improve global recognition and utilization of green ICT. Various efforts are needed in order to change public perceptions, through the promotion of a systematic education system that could improve individual ICT utilization capacity and the government's green ICT. Third, the distribution of green ICT between the government and corporations should be reinforced. The basis should be prepared for planning more advanced smart cities, by promoting the establishment, investment and development of ICT infrastructure between the government and corporations.

\section{References}

[1] S. M. Rue, "Smart City Trand Analysis and Case Study", Journal of Korean Institute of Information Technology, vol.12, no.1, (2014), pp.19-28.

[2] Y. Park and S.M. Rue, "Analysis on Smart City Service Technology with IoT", Journal of Korean Institute of Information Technology, vol.31, no.37, (2015), pp.31-37

[3] B.-W. Kim, "The Forth Industrial Revolution: Industrial Internet of Things", Journal of Law \& Economic Regulation, vol.9, no.1, (2016), pp.215-232.

[4] Policy Research Division Fusion Policy Research Department, "Smart City Promotion Analysis of Major Countries in the World", Published by Korea Broadcasting and Communications Agency, (2014), pp. 57-69.

[5] S. M. Rue, "Smart City Trand Analysis and Case Study", Journal of Korean Institute of Information Technology, vol.12, no.1, (2014), pp.19-28

[6] https://www.linkedin.com/pulse/making-delhi-smart-city-sonia-kathuria.

[7] G. Y. Lee Editor, "ICT Standardization Strategy Map 2012", Telecommunications Technology Association, (2012), pp.1-230.

[8] G. Y. Lee Editor, "ICT Standardization Strategy Map 2012", Telecommunications Technology Association, (2012), pp.1-230.

[9] W. Shin and Y. Jo, "Smart city-building efforts and implications of the UK Government", Korea Research Institute For Human Settlements, May 2016, vol. 415, (2016), pp.86-92.

[10] Policy Research Division Fusion Policy Research Department, "Smart City Promotion Analysis of Major Countries in the World", Published by Korea Broadcasting and Communications Agency, (2014), pp. 57-69.

[11] Y. Han, "Smart City spread abroad background and Implementation Status", Journal of Korean Electric, May 2016, vol.473, (2016), pp.26-31.

[12] https://www.energystar.gov/about/origins_mission/epas_role_energy_star.

[13] https://www.energystar.gov/about/content/energy-star-annual-report-released-americans-saved-12billion-2005.

[14] H. Kim, S. Kim, S. Seol, H. Kim, Y. Kim and J. Lim, "A Study on Green ICT Strategies in Korea", Journal of Environmental Policy and Administration, vol. 18, no.2, (2010), pp.139-161.

[15] Y.-W. Kim and H. Kim, "Green ICT Technology Development and Standardization Activities", Communications of the Korean Institute of Information Scientists and Engineers, vol. 29, no. 3, (2011), pp.44-52.

[16] Green Growth of Korea, "The First of Low-carbon green growth for 5-Year Plan”, Korea Ministry of Knowledge Economy, (2009-2013).

[17] Green Growth of Korea, "The First of Low-carbon green growth for 5-Year Plan", Korea Ministry of Knowledge Economy, (2009-2013).

[18] Green Growth of Korea, "The Second of Low-carbon green growth for 5-Year Plan", Korea Ministry of Knowledge Economy, (2014-2018).

[19] Green Growth of Korea, "The Second of Low-carbon green growth for 5-Year Plan", Korea Ministry of Knowledge Economy, (2014-2018). 
International Journal of Advanced Science and Technology

Vol.112 (2018) 